\title{
A tale of two statues Contemporary conflict reporting constraints and the Battle of Baghdad
}

\begin{abstract}
Although television conflict reporting has usually been limited by risks to journalists' safety, the death throes of Ba'athist Iraq in April 2003 provided viewers with a unique opportunity to vicariously witness the fall of a large modern city. Yet if the iconic moment of the Second Gulf War came when Saddam Hussein's statue in Firdos Square was toppled, then it was at the expense of another image event which unfolded earlier a short distance away. The US military's violent destruction of the equestrian statue close to the 'Hands of Victory' monument better encapsulated the conflict than the sterile bloodless 'cakewalk' description with which it is usually labelled. This article demonstrates how the tale of these two statues is also in some ways the tale of two Fox News correspondents; and how an alienation from military service conditions and methods can leave reporters and their audiences with no sense of what the participants on their screens endured in order to reach Baghdad; or what they had also inflicted upon others. In retrospect, the circumstances which allowed one Fox reporter to provide the world with what might have been its first taste of live, unedited combat footage seem more like an accidental success than the result of systematic best practices. This is so even when this network and even its most credible host work to ensure a partisan perspective dominates all their broadcasts.
\end{abstract}

Keywords: best practice, combat footage, conflict reporting, Iraq, military, Operation Iraqi Freedom, television, trauma, war correspondence

\section{STEVE ELLMERS}

Unitec, Auckland

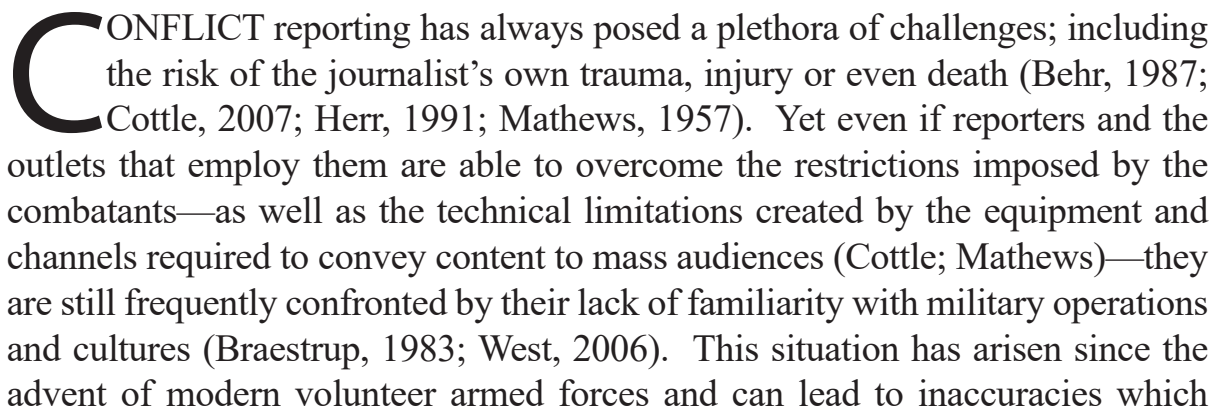


unintentionally distort the impressions of publics and political decision makers alike (Braestrup; Reynolds, 2007; United States Army Center of Military History, 2010; Yetiv, 1997). However, despite the industry's use of expert opinion and studio 'talking heads' to augment the dwindling number of journalists with prior military service (Poole, 2003; Greg Kelly recounts, 2008), it appears to be the political constraints within some media organisations which ultimately shape what aspects they cover, even when this minimises the achievements of a conflict's participants or disguises their failures.

At the start of the 21 st century, the United States embarked on a military adventure in Iraq that threatened the country's global prestige in a way not seen since the Vietnam conflict (Judt \& Lacorne, 2005; Stam \& Shohat, 2007). Although there was a tendency to portray this campaign as a continuation of the Kuwait crisis (Reynolds, 2007; Woods, 2008; Woods, Palkki \& Stout, 2011), it became a profoundly different conflict to the one audiences were told to expect (Ricks, 2006). This affected the way some outlets and individual reporters portrayed the death throes of Ba'athist Iraq on April 9, 2003. Television coverage has a tendency to create image-centric experiences which audiences find more compelling than text-based accounts (Eveland \& Seo, 2007). When television is the main source of news information for most Americans (Lin, 2009), their ability to make sense of what is unfolding as a result of their government's foreign policy initiatives can be affected by what they can see as well as what they cannot. This selective framing (Scheufele, 1999) is similar to what US viewers were exposed to in the First Gulf War in January and February 1991 when CNN dominated the airwaves in the US. This time, however, CNN had been partially superseded by a rival 24 hour news channel, Fox News (Collins, 2004).

\section{The wars that weren't?}

When first published, French philosopher Jean Baudrillard's (1995) assertions that the First Gulf War would not take place, was not really taking place, and therefore did not take place, seemed highly contentious. Baudrillard contended that the constant broadcasting of precision air strike footage obscured the real cost of those operations and of the conflict as a whole. Interestingly, although for slightly different reasons, this was the same conclusion reached by branches of the US military (United States Department of Defence - hereinafter US DoD, 1992) as well Saddam's regime (Woods, 2008). This realisation also influenced how the initial stages of the Second Gulf War between March 20 and April 10 would be conducted and reported. The media pooling system implemented by coalition forces during the First Gulf War created widespread resentment among the news teams covering the conflict (Kelly, 2001). Because the US DoD insisted that only journalists from coalition countries such as America, the UK and France could accompany the ground forces involved in Iraq's eviction from Kuwait, 
most of the world's media had to rely on the daily briefings provided by Central Command in Riyadh, Saudi Arabia (Cottle, 2007). This meant there was a similar environment to the infamous Five O'Clock Follies used to brief reporters in Saigon during the Vietnam conflict (Braestrup, 1983; Herr, 1991). However, while the official summaries of the day's events could include thermal imagery of laser-guided bombs destroying multi-story buildings in Baghdad, whatever limited news video of ground operations could be gathered was censored to prevent Iraq from acquiring intelligence on Coalition movements (Schwarzkopf, 1992). The journalists assigned by lottery to various units were usually only able to gather information from divisional or brigade level headquarters due to the risks inherent in intensive mechanised operations (Cordingley, 1996; ibid.). They were also dependent on the forces they were with for satellite transmission of their recordings; a task that was not a high priority during the four-day blitzkrieg which saw some Coalition forces threatened with immobilisation through either a lack of supplies or sheer exhaustion (Yetiv, 1997).

The culmination of the campaign's limited objectives was the liberation of Kuwait City (US DoD, 1992) and it was this event which finally gave American television news the images they wanted. In an eerie parallel with the scenes witnessed just over 12 years later, viewers in 1991 were also confronted with pictures of jubilant civilians and victorious US Marines celebrating an Iraqi military disaster (NBC News: Liberation of Kuwait, February 1991, 2014). Yet the prominence given to the Marines, despite the diversionary aspects of their contribution convinced the US Army that a new media management policy was required to highlight their role in any future conflict. This system of embedding, under which journalists could travel with the headquarters elements of units as small as battalion or even task force size, was tested during its deployments to Bosnia (Atkinson, 2004) and was one which randomly selected journalists would benefit from in the Second Gulf War (ibid.; Poole 2003; Ricchiardi, 2003; West \& Smith, 2003).

The arbitrary nature of the embedding programme meant reporters could not anticipate which units they would be assigned to. The programme had also been expanded to include all the service arms of the US forces, as well as Allied contingents such as the British Army's 1st Armoured Division. Correspondents such as the Evening Standard's Oliver Poole (2003) — who had previously served in Britain's Territorial Army - were keenly aware of the different opportunities available between joining an American armoured battalion expected to seize the Iraqi capital and a placement on board a US Navy vessel or with a logistics unit. Unlike virtually every one of his contemporaries, Poole was not estranged from his country's armed forces and was familiar with military procedures; though admittedly, not the shared beliefs and assumptions of the American Army. The aspect of the embedding system which most surprised some of the journalists 
involved was the level of access they were granted (Greg Kelly recounts, 2008; Poole; Ricchiardi, 2003). However, this very access raises concerns about whose views the embedded reporters were able or expected to convey.

Influential communications scholars such as Edward Herman (1999) and Daniel Hallin (1997) have long been concerned about media coverage which emphasises official sources and perspectives. They believe this allows government sources to dominate the discourse surrounding controversial issues, while marginalising those who oppose the policies governments attempt to implement. When the policy being debated is whether to intervene militarily in another nation state (Ricks, 2006; Woodward, 2004), then how elite opinions are portrayed can be critical in determining public opinion (Hallin, 1986). The build-up to the Second Gulf War was marred by intense debates within the administration of George W. Bush and throughout the capitals of America's traditional friends (Ricks; Woodward). Yet because the US government's divisions were only occasionally aired in public and Bush's Democratic rivals feared appearing 'soft' on national security issues in the aftermath of 9/11 (Ricks), domestic elite views opposing the invasion struggled to attain what Hallin (1986) describes as a level of legitimate controversy. International reluctance to participate in Saddam's removal also resulted in concerted attacks on French 'intransigence' (House now serving 'freedom fries', 2003) — despite France's long-standing involvement with an under-reported aerial campaign designed to contain Iraq in the aftermath of the First Gulf War (Woodward, 2004). Ironically, the television network leading these attacks also employed a field reporter who had participated in those air strikes.

Fox News Corporation's Greg Kelly was a US Marine Corps aviator who, at the onset of the Second Gulf War, was still an officer in the Marine Reserves (Coscarelli, 2012; Greg Kelly recounts, 2008). Although his operational experience was as a pilot, he was assigned to the US Army's 3rd Infantry Division (Mechanised) prior to its crossing of the Iraq/Kuwait border. His live broadcasts from the back of an armoured vehicle were only possible because of the advances in satellite communications that had occurred since 1991 (Inmarsat award, 2014).). The increased portability of the systems used by coalition and reporters alike enabled Kelly to stream continuous footage back to the US accompanied by his improvised comments (Greg Kelly recounts, 2008; The thunder run, 2010). However, it was his previous immersion in the US military which enabled him to appreciate the calibre of the soldiers alongside whom he was working (Ricks, 1997). Regardless of the inter-service rivalry between the Army and the Marines, Kelly appeared to genuinely admire the overall training and professionalism of the Division's 2nd Brigade (Greg Kelly recounts. 2008). His ability to straddle this societal divide between those intimately aware of the challenges facing service personnel and their families and those who are not (Wright, 2008), coincided with the overwhelmingly pro-invasion coverage of Fox News in general (Lin, 
2009). Yet within an outlet known for its strident jingoism and paucity of indepth analysis on anything other than Republican Party machinations (Swint, 2008), Kelly's measured and informative statements stood in stark contrast to Fox's usual fare. However, even after taking his personal performance into account the initial images Kelly provided of unopposed thrusts into Western Iraq still conformed to Baudrillard's (1995) idea of a bloodless misrepresentation-one which also rested on the myths and illusory lessons of the First Gulf War.

The performance of the Iraqi military during the Kuwaiti crisis was analysed by Iraq as well as its opponents. Although both sides were tempted to attribute the Iraqi collapse to the extensive airpower used against them, there was a shared sense that airpower alone would not be sufficient to thwart Saddam in any future crisis (Woods, 2008; USACMH, 2010). Nonetheless, the Iraqis considered that their opponents wanted to keep the level of their own casualties low and also sensitive to charges they were responsible for the indiscriminate killing of civilians (Woods; Woods et al., 2011). As a result, Iraq appears to have made a conscious decision to avoid utilising its residual mechanised forces in open terrain. Instead, infantry armed with light anti-tank weapons and assault rifles would attempt to inflict politically unacceptable losses on coalition units in the hope that this might lead to a negotiated settlement and leave Saddam with control over his capital and the central Sunni regions of the country (Woods, Pease, Stout, Murray \& Lacey, 2006). Coalition forces were also aware of this possibility and, as they approached Baghdad at the end of March 2003, the idea of having to operate armoured vehicles in an urban setting while defeating the Saddam Fedayeen and other paramilitary forces weighed heavily on senior commanders (Reynolds, 2007). However, one solution to this dilemma was to destroy the regime's centre of gravity (von Clausewitz, 1982; Gordon \& Trainor, 2007; Zucchino, 2004a), and drive straight for Saddam's palace complexes.

This concept was originally deemed too ambitious by the 3rd Division's commander General Buford Blount. As a compromise, an initial 'thunder run' was ordered through the outskirts of Baghdad and it was this enterprise that Fox's Greg Kelly was to broadcast live on April 5 (Lacey, 2007). This time, Kelly had a remarkable scoop. Rather than a monotonous vista of dirt and dust (Greg Kelly recounts, 2008) audiences around the world could witness the transformation of a large city's impressive roads and infrastructure into a confusing and chaotic battlefield. Kelly's footage contains some disturbing material such as a civilian car, whose occupants must be either dead or dying, slamming into the median barrier of a modern motorway after passing between two of the armoured vehicles with which he was travelling (The thunder run, 2010). However, although we also see Staff Sergeant Jason Diaz's burning and abandoned Abrams tank — an early indicator that the engagement was not entirely one-sided (ibid.; Zucchino, 2004a) — the mere fact that Kelly and his cameraman Mal James were able to stand up and record 
their footage demonstrates that any firing we can hear is mainly, if not entirely, outgoing, and therefore American. His description of the 'civilian vehicles, white pick-up trucks [which] come at us almost on suicide missions' is not as far-fetched as it first seems (Greg Kelly reflects, 2010). For instance, after the fall of Baghdad large quantities of regime documents were captured and analysed which showed the pre-war efforts of the Saddam Fedayeen to develop unconventional capabilities involving car bombs and suicide vests (Woods \& Lacey, 2007). Yet in other parts of the city residents were attempting to go about their affairs while unaware of the depth of the American penetration (The thunder run, 2008; Zucchino, 2004a). Kelly appeared unwilling or unable to explore this paradox. The Americans' desire to minimise their own casualties created an environment in which any vehicle approaching the column was considered a threat. Although he explained that some of the civilian vehicles destroyed produced secondary explosions which might indicate they contained munitions of some sort (Greg Kelly recounts, 2008), he never fully addresses how feasible it was for Iraqi motorists to interpret machine-gun tracer fire into the road in front of them as a signal to slow down and stop (The thunder run, 2008; Zucchino, 2004a). This failing caused him to inadvertently become a source only capable of conveying the views of the organisation upon whom he was meant to be reporting.

After watching Kelly's video, General Blount was convinced Saddam's forces were on the brink of total collapse and approved a thrust aimed at the symbols of the regime's rule (Lacey, 2007). This was considered so risky that on April 7 only main battle tanks were initially used and all crews were to remain inside their vehicles with their hatches secured (Zucchino, 2004a). As a result, at first the Fox News team was unable to accompany the forces employed and even when it was deemed safe enough to use the more lightly armoured M113s in which they usually rode, the threat of hostile small arms and rocket propelled grenade fire prevented Fox from securing any additional footage. The only broadcasting Kelly did that day was at the behest of the 2nd Brigade's commanding officer Colonel David Perkins. He and cameraman Mal James briefly left the relative safety of their vehicle to film a short piece to camera on the steps of one of Saddam's gaudy palaces (Zucchinoa). However, this was not the only proof that American forces had been right into the city's centre. Determined to prove the inaccuracy of Iraqi Information Minister Muhammad Saeed al-Sahhaf's statements, Perkins allowed his troops to put a tank main gun round into Saddam's equestrian statue by the 'Hands of Victory' Monument (ibid.; Soldiers destroying statue in Iraq, 2006) in case his lack of fuel caused him to withdraw. This violent destruction of the Iraqi leader's image was more emblematic of the entire campaign; one which was far from 'bloodless' or devoid of risk and which by this stage had already cost the lives of thousands of Iraqis (Conroy \& Martz, 2005; Lacey). However, all this was to be overshadowed by the fate of another statue a short distance away. 


\section{Run to Paradise}

The most memorable images from the Battle of Baghdad and indeed, the entire Second Gulf War, were provided on April 9 in Firdos Square, just across the Tigris River from where the 3rd Infantry continued to engage in occasionally intense firefights (Conroy \& Martz, 2005). Once again, although still acting in a diversionary role, (Reynolds, 2007; West and Smith, 2003) the US Marine Corps was to take centre stage in a defining image event. Neither Fox nor any other news outlet had reporters embedded with the Marines responsible for the toppling of the large statue of Saddam. Although there were discussions by senior commanders about the need to find targets that demonstrated the end of Ba'athist rule (Reynolds, 2007), this had not initially been conveyed to the Marines in Firdos Square. As the Iraqi Information Ministry minders who always accompanied the foreign media had failed to turn up for work that morning, the international correspondents already in Baghdad knew the regime had collapsed (Zucchino, 2004a). While strolling a short distance from their hotel they encountered a small group of Iraqis gathered in the square, intent on destroying any symbols of Saddam they could find (McLaughlin, 2008). However, the statute on which they were venting their fury proved impervious to all their efforts. The arrival of the Marines dramatically changed the dynamics of the situation (ibid.) and, at the suggestion of a US Army psychological operations team (Zucchino, 2004b), they used one of their armoured recovery vehicles to topple the statue, to the evident delight of the crowd (Saddam statue falls, 2012).

This footage was beamed around the world by Abu Dhabi TV and quickly picked up by Fox News Corporation. At Fox's headquarters, a studio team comprising their most senior commentators provided their own contextualisation. One of them was Brit Hume, a former ABC News chief White House correspondent who had previously won an Emmy for his work during the First Gulf War (On air personalities, n.d.). Hume and other members of Fox News would have been aware of the potential for historic drama over the coming days. Nor could they have been unaware of Fox's role in the continuous campaign mode of America's Republican Party (Swint, 2008). He described the events in Firdos Square as being 'extraordinarily effective in conveying to the world what the [G. W. H. Bush] administration said and promised it was trying to achieve' (Saddam statue falls, 2012). Hume had become what Herman (1999) would call a primary definer, effectively acting as spokesperson, through Fox, for the government's position. He went on to declare:

If this had been planned in some way [the destruction of the statue], and manifestly it was not, [as] we can tell, it could hardly be a more effective and powerful message. 
Yet, as Los Angeles Times correspondent David Zucchino (2004b) showed, there was a degree of opportunistic manipulation of the crowd by the US military that day. Equally importantly, what the footage from Firdos Square did not show was the widespread looting and sporadic fighting that was occurring only a few blocks away (Zucchino, 2004a). In many ways the events in Firdos Square could be said to have been the highpoint of the US invasion of Iraq (Ricks, 2006). As Iraq began to spiral into the abyss, perhaps the most powerful message of April 9 was not the new American global assertiveness to which Brit Hume intended to draw attention; but rather the limits of US influence and decision making.

\section{References}

Atkinson, R. (2004). In the company of soldiers: A chronicle of combat in Iraq. New York, NY: Henry Holt and Company.

Baudrillard, J. (1995). The Gulf War did not take place. Bloomington, IN: Indiana University Press.

Behr, E. (1987). Anyone here been raped and speaks English? New York, NY: Viking Press.

Braestrup, P. (1983). Big story: How the American press and television reported and interpreted the crisis of Tet 1968 in Vietnam and Washington. New Haven, CT: Yale University Press.

Chenoweth, N. (2002). Rupert Murdoch: The untold story of the world's greatest media wizard. New York, NY: Crown Business.

von Clausewitz, C. (1982). On war. London, England: Penguin.

Collins, S. (2004). Crazy like a fox: The inside story of how Fox News beat CNN. New York: Penguin Group.

Conroy, J., \& Martz, R. (2005). Heavy metal: A tank company's battle to Baghdad. Dulles, VA: Potomac Books.

Cordingley, P. (1996). In the eye of the storm: Commanding the Desert Rats in the Gulf War. London, England: Hodder and Stoughton.

Coscarelli, J. (2012, January 26). Meet Greg Kelly: The fighter pilot, war reporter, news anchor, and police commissioner's son accused of rape. New York Magazine. Retrieved from http://nymag.com

Cottle, S. (2007). Mediatized conflict. Retrieved from EBL database.

Drew, D., \& Weaver, D. (2006). Voter learning in the 2004 presidential election: Did the media matter? Journalism and Mass Communication Quarterly, 83(1), 25-42. Retrieved from http://jmq.sagepub.com

Eveland, W., \& Seo, M. (2007). News and politics. In D. R. Roskos-Ewoldsen and J. L. Monahan (Eds.). Communication and social cognition: Theories and methods. Retrieved from EBL database.

Gordon, M. R., \& Trainor, B. E. (2007). Cobra II: The inside story of the invasion and occupation of Iraq. New York, NY: Vintage Books.

Greg Kelly recounts his ride into Baghdad. (2008). Retrieved from www.youtube.com/ watch? $v=$ gyjRNbi8BBM

Greg Kelly reflects on his coverage of Iraq. (2010). Retrieved from www.youtube.com/ watch? $=\mathrm{gpVLQLOYYNs}$ 
Hallin, D. C. (1986). The 'uncensored war': The media and Vietnam. Retrieved from Ebrary database.

Hallin, D. (1997). The media and war. In J. Corner, P. Schlesinger, \& R. Silverstone (Eds.). International media research: A critical survey. (pp. 206-231). New York, NY: Routledge.

Herman, E. (1999). The myth of the liberal media. New York, NY: Peter Lang Publishing. Herr, M. (1991). Dispatches. New York, NY: Vintage Books.

House now serving 'freedom fries'. (2003, March 11). Retrieved from www.foxnews. com/story/2003/03/11/house-now-serving-freedom-fries

Inmarsat honoured with prestigious IVCA award. (2014). Retrieved from www.inmarsat. com/news/inmarsat-honoured-prestigious-ivca-award

Iraq Survey Group. (2004). Comprehensive report of the Special Advisor to the DCI on Iraq's WMD. Retrieved from www.cia.gov/library/reports/general-reports-1/ iraq_wmd_2004

Judt, T., \& Lacorne, D. (Eds.). (2005). With us or against us: Studies in global antiAmericanism. Retrieved from Ebrary database.

Kelly, M. (2011). Martyrs'day: Chronicle of a small war. New York, NY: Vintage Books.

Lacey, J. (2007). Takedown: The 3rd Infantry Division's twenty-one day assault on Baghdad. Annapolis, MD: Naval Institute Press.

Lin, C. A. (2009). Selective news exposure, personal values, and support for the Iraq War. Communication Quarterly, 57(1), 18-34. doi:10.1080/01463370802662440

Mathews, J. J. (1957). Reporting the wars. Retrieved from Ebrary database.

McLaughlin, T. (2008, March 18). From 9/11 to fall of Baghdad, an ex-Marine explains what it means to him. The New York Times. Retrieved from www.nytimes.com

NBC News: Liberation of Kuwait, February 1991. (2014). Retrieved from www.youtube. $\mathrm{com} /$ watch? $\mathrm{v}=8581 \mathrm{vXand} 1 \mathrm{U}$

On air personalities. (2008). Retrieved from www.foxnews.com/on-air/personalities/ brit-hume/bio/\#s=h-1

Poole, O. (2003). Black knights: On the bloody road to Baghdad. New York, NY: HarperCollins.

Reynolds, N. E. (2007). US Marines in Iraq, 2003: Basrah, Baghdad and beyond. Washington, DC: United States Marine Corps History Division.

Ricchiardi, S. (2003). Close to the action. Retrieved from http://ajrarchive.org/article. asp?id=2991

Ricks, T. E. (1997). Making the corps. New York, NY: Scribner.

Ricks, T. E. (2006). Fiasco: The American military adventure in Iraq. New York, NY: Penguin Press.

Ricks, T. E. (2009). The gamble: General David Petraeus and the American military adventure in Iraq, 2006-2008. New York, NY: Penguin Press.

Saddam statue falls. (2012). Retrieved from www.youtube.com/watch?v=4uyttSrkW6Q

Scheufele, D. A. (1999). Framing as a theory of media effects. Journal of Communication, 49(1), 103-122. Retrieved from http://onlinelibrary.wiley.com/journal/10.1111/ (ISSN)1460-2466

Schwarzkopf, N. (1992). It doesn't take a hero. New York, NY: Bantam Books.

Soldiers destroying statue in Iraq (2006). Retrieved from www.youtube.com/ watch? $\mathrm{v}=$ TsUeq48ALsc

Stam, R., \& Shohat, E. (2007). Flagging patriotism: Crises of narcissism and anti-Americanism. New York, NY: Routledge.

Swint, K. (2008). Dark genius: The influential career of legendary political operative 
and Fox News founder Roger Ailes. New York: Sterling Publishing.

The thunder run, US 3rd Infantry Division's drive to Baghdad. (2010). Retrieved from www.youtube.com/watch? $\mathrm{v}=\mathrm{a} 9 \mathrm{oQpBH} 9 \mathrm{Zcw}$

United States Army Center of Military History. (2010). War in the Persian Gulf: Operations Desert Shield and Desert Storm August 1990-March 1991. Washington, DC: Author.

United States Department of Defense. (1992). Conduct of the Persian Gulf War: Final report to Congress. Washington, DC: Author.

West, B. (2006). No true glory: A frontline account of the battle of Fallujah. New York, NY: Bantam Dell.

West, B. (2008). The strongest tribe: War, politics, and the endgame in Iraq. New York, NY: Random House.

West, B., \& Smith, R. L. (2003). The march up: Taking Baghdad with the 1st Marine Division. New York, NY: Bantam Dell.

Woods, K. M. (2008) Um al-ma'arik (The mother of all battles): Operational and strategic insights from an Iraqi perspective (Vol. 1). Alexandria, VA: Institute for Defense Analyses.

Woods, K. M., \& Lacey, J. (2007). Iraqi perspectives project-Saddam and terrorism: Emerging insights from captured Iraqi documents (Vol. 1). Alexandria, VA: Institute for Defense Analyses.

Woods, K. M., Palkki, D. D., \& Stout, M. E. (Eds.). (2011). The Saddam tapes: The inner workings of a tyrant's regime, 1978-2001. Cambridge, UK: Cambridge University Press.

Woods, K. M., Pease, M. R., Stout, M. E., Murray, W., \& Lacey, J. G. (2006). Iraqi perspectives project: A view of Operation Iraqi Freedom from Saddam's senior leadership. Alexandria, VA: Institute for Defense Analyses.

Woodward, B. (2004). Plan of attack. New York, NY: Simon and Schuster.

Wright, E. (2008). Generation kill. New York, NY: Berkley Publishing.

Yetiv, S. A. (1997). The Persian gulf war. Westport, CT: Greenwood Press.

Zucchino, D. (2004a). Thunder run: The armoured strike to capture Baghdad. New York, NY: Grove Press.

Zucchino, D. (2004b, July 3). Army stage-managed fall of Hussein statue. The Los Angeles Times. Retrieved from www.latimes.com

Steve Ellmers is a postgraduate student in the Master of International Communication at Unitec in Auckland. An earlier version of this article was presented at the Pacific Journalism Review '20 Years of Publishing' Political Journalism conference at Auckland University of Technology in November 2014.

sjellmers@gmail.com 